\title{
WOMEN'S EXPERIENCES OF THE JUSTICE SYSTEM
}

\author{
Joanne Morris*
}

This article considers the impact of gender upon women's experiences of the New Zealand justice system, as lawyers and as clients. As well as summarising study and survey material, it draws upon information provided to the Law Commission in the course of its project on Women's Access to Justice: He Putanga mo nga Wahine ki te Tika. It concludes that women are still significantly disadvantaged by the justice system as a result of their gender and that there is an ongoing need for debate and consideration of these issues if women's access to justice is to be improved.

\section{WOMEN'S ACCESS TO JUSTICE PROJECT}

In the course of the Law Commission's project on Women's Access to Justice: He Putanga mo nga Wahine ki te Tika, thousands of New Zealand women have spoken or written to us about their experiences as clients of various parts of the justice system. Many of the women believe they have not always been treated fairly by the lawyers, Judges and others involved, and often for reasons connected with gender. While the variety of their experiences reveals a range of ways in which law, its processes and personnel can fail to meet women's expectations of just treatment, the project is focusing on what may be regarded as the two most basic problem areas.

The first area, marked out by the sheer weight of the criticisms made about it, comprises the impediments to women's access to legal services. The titles of six of the project's consultation papers indicate the boundaries of this area: Information About Lawyers' Fees (NZLC MP3), Women's Access to Legal Information (NZLC MP4); Women's Access to Civil Legal Aid (NZLC MP8); Women's Access to Legal Advice and Representation (NZLC MP9), Lawyers' Costs in Family Law Disputes, and Lawyers' Education (both to be published shortly).

The other area embraces Maori women's concerns about the "justice system", broadly defined to extend beyond the activities of the justice sector but with particular reference to

- Law Commissioner, New Zealand Law Commission - Te Aka Matua O Te Ture. 
that sector and to the delivery of legal services. A consultation paper which presents those concerns in a cultural and historical context will be published later in 1997.

Although the Women's Access to Justice project is not focused directly on gender equity in the New Zealand judicial system, a great deal of information relevant to the subject has been gathered during the project's consultative processes. Because those processes have included extensive consultation with lawyers, the information collected relates not only to women clients' but also women lawyers' experiences of disadvantage for reasons connected with gender.

\section{SCOPE OF PAPER}

This paper focuses upon the impact of gender, first, on New Zealand women lawyers' prospects in the legal profession and secondly, on women lawyers' and women clients' experiences in court. Throughout, I will relay examples provided to the Law Commission, all of which, to the best of my knowledge, relate to events which have occurred within the last five years. As well, I will incorporate findings from a 1992 study of Women Lawyers in New Zealand conducted by Gill Gatfield and Alison Gray and from the three 1997 New Zealand Law Society Polls: of Lawyers, the Public, and Law Firms.

\section{GENDER}

The Australian Law Reform Commission has described gender as the social construction of male/female identity which develops over time and is so influential as to be part of a society's culture - part of our understanding of the way things are. More particularly: ${ }^{1}$

Gender describes more than biological differences between men and women. It includes the ways in which those differences, whether real or perceived, have been valued, used and relied upon to classify women and men and to assign roles and expectations to them.

The significance of this is that the lives and experiences of women and men, including their expectations of the legal system, occur within complex sets of differing social and cultural expectations.

The demographic and economic facts of New Zealand life, coupled with the facts about the incidence of violence against New Zealand women, provide an excellent foundation for an appreciation of the thoroughgoing effects of gender upon women and men in our society. Those facts reveal that New Zealand women as a group, compared with New Zealand men as a group, have been disadvantaged in the past in terms of access to resources, social status and credibility, and that, despite very welcome improvements, the disadvantage continues.

1 The Law Reform Commission Equality Before the Law: Justice For Women: DP54 (The Law Reform Commission, Sydney, 1993) 1. 
Of course, there are many factors other than gender which are associated with socioeconomic disadvantage - such as ethnicity, age, sexuality and mental and physical ability and which affect, often profoundly, groups made up of both men and women. But those factors operate in an environment in which gender counts, with the result that they do not have identical effects for men and women. For women, as is plain from the statistics, and as has been emphasised in the Law Commission's many meetings - especially with Maori women, Pacific women, lesbians and disabled women - gender compounds other causes of disadvantage. $^{2}$

\section{GENDER AND THE LEGAL PROFESSION}

While we are all aware that women outnumber men these days at the gates of the legal profession, it is instructive to recall how many years it took to reach this position. Before the passage of the Female Law Practitioners Act in 1896, women were barred by law from practising it. Our first woman lawyer, Ethel Benjamin, was admitted in 1897. But, it was not until some twenty five years ago that women began entering the legal profession in any numbers.

Just 26 years ago, in 1971, women comprised less than $4 \%$ of the annual intake to the legal profession. In $1981,30 \%$ of the new admissions were women; in 1985, $45 \%$ were women, and in 1991 women slightly outnumbered men for the first time. 1996 was a record year: of the 709 people admitted to legal practice, $54 \%$ (381) were women. ${ }^{3}$

For the last decade then, women have been entering the profession in numbers more than, or nearly, equal to those of men and for the five years before that women accounted for about one third of new admissions. The most recent full analysis of what happens beyond the gates of the profession reflects the situation at the end of $1995 .^{4}$

At that time there were 6996 practising lawyers in New Zealand, including nearly 1900 women lawyers $(27 \%)$. Using the percentages provided by the New Zealand Law Society

2 While the uniting effects of gender upon women's life experiences underlie the Law Commission project's focus upon women's Access to Justice, its recognition that women are not a homogeneous group, and its emphasis upon the effects of women's diversity on their access to justice, ensure that its insights and proposals for change will be of benefit to both women and men.

3 Figures supplied by New Zealand Law Society.

4 NZLS 99th Annual Report, 6 (reproduced in LawTalk 452, April 1996). 
as well as rounded numbers, men and women were distributed across the four categories of legal practice as follows:

- Principals (42\% of all lawyers): 2660 men, 340 women

- Employees in private practice (37\% of all lawyers): 1500 men, 1100 women

- Barristers sole ( $8 \%$ of all lawyers): 445 men, 140 women

- Others (12\% of all lawyers): 500 men, 320 women. ${ }^{5}$

Proportionate to their numbers then, women lawyers were significantly overrepresented in the profession as employees in private practice $(58 \%$ of all women lawyers were employees compared with $29 \%$ of all men lawyers) and significantly underrepresented as principals ( $18 \%$ of all women lawyers were principals compared with $52 \%$ of all men lawyers). Women were over-represented in the "other" category ( $17 \%$ of all women lawyers were in this category compared with $10 \%$ of all men lawyers) but had attained near parity, proportionally, as barristers sole $(7 \%$ of all women lawyers were barristers sole compared with $9 \%$ of all men lawyers).

It is often said that, in light of the number and proportion of women being admitted to the profession these days, it is only a matter of time before women lawyers will be represented in equal numbers to men at the top of the profession. I am certain that it is not that simple: time will help but, by itself, it will not be enough. This view is supported by Gatfield and Gray's study and also by the recently released results of the New Zealand Law Society's Poll of Lawyers.

The Gatfield and Gray study ${ }^{6}$ was based on a questionnaire returned by nearly one quarter of New Zealand lawyers with practising certificates in 1992: 1469 lawyers responded - 784 women and 685 men. One matter the study explored was the career aspirations of women and men lawyers with the same length of experience and it found that the women's career aspirations were at least as high as the men's. Interestingly though, women were more likely then men to aspire to be:

- a partner in a firm other than the one they were already in;

- a sole practitioner in 5 or more years time; and

- a District Court Judge in 10 years time. ${ }^{7}$

5 This category includes lawyers in the public sector, trade associations and commercial entities.

6 G Gatfield and A Gray Women Lawyers in New Zealand: A Survey of the Legal Profession (Equity Works, Wellington, 1993).

7 Above n 6, 20. 
A cynic might say that women's main aspirations were to get out of the workplace they were in at the time they answered the questionnaire!

Despite the women's career aspirations being at least as high as those of the men, the study found that:

- men obtained partnerships in a shorter time than women;

- women spent twice as long as men as associates; and

- across all occupational categories, women lawyers earned less than men lawyers with the same number of year's experience, with the difference in earnings increasing after five years experience. ${ }^{8}$

These findings cannot be directly compared with any from the Poll of Lawyers ${ }^{9}$ because the Poll did not explore the career aspirations, or the earnings, of men and women with the same number of years experience. The Poll was conducted by means of a self-completion survey returned by 670 lawyers whose characteristics as a group are similar to the characteristics of the population of lawyers, one result of which is that over $70 \%(485)$ of the lawyers polled are men and under $30 \%$ (173) are women.

The Poll did find that one of the main aims of $36 \%$ of the women polled, and $29 \%$ of the men, is "getting to the top of my profession"10 and that women working full-time in the profession ${ }^{11}$ earn less than men but, as is true for the wider population of lawyers, the women polled tended to have been admitted more recently than men which would account for some of these differences. ${ }^{12}$

The results from the Poll of Lawyers are, however, directly relevant to Gatfield and Gray's finding that there are three major obstacles to women lawyers reaching their career goals:

- work experience;

- discrimination; and

8 Above n 6, 9-12.

9 The New Zealand Law Society Poll of Lawyers (MRL Research Group, Wellington, 1997).

$1019 \%$ of the men polled and $6 \%$ of the women said they were already at the top of their profession. The lawyers ( $57 \%$ of women and $51 \%$ of men) who said that getting to the top is not one of their main aims are more likely to work in suburbs or towns, compared to a CBD. Above $n$ 9,166 .

11 Whether as employees, partners, barristers sole or "other".

12 Above n 9, 183. 
- family commitments.

These will be explored in turn.

\section{A Work Experience}

The nature of lawyers' work experience is obviously an important factor in determining their advancement within the profession, especially because of its effects upon fee performance - which was ranked by both men and women lawyers in the Gatfield and Gray study as being the top criterion for being made a partner. ${ }^{13}$

The study found there were three areas of law in which women were significantly more likely to be working than men - criminal law, family law and District Court litigation - and that criminal law was ranked by most lawyers as offering the poorest prospects for advancement within the profession. It also found there were three areas of law in which men were significantly more likely to be working than women - commercial law, commercial conveyancing and domestic conveyancing - and that commercial law was ranked by most lawyers as offering the best prospects for advancement. ${ }^{14}$

The Poll of Lawyers tends to confirm these results. While it does not reveal any areas of law in which women are significantly more likely to be working than men, it does show that women and men are equally or almost equally involved in four areas: criminal law, family law, central or local government matters, and energy and resource law. ${ }^{15}$ Two of those four, criminal law and family law, are amongst the eight areas most often rated by lawyers as being not prestigious. ${ }^{16}$

The Poll also shows that men are significantly more likely than women to be working in four areas: commercial conveyancing, investment advice, company and commercial law and tribunals. ${ }^{17}$ The first three of those areas are amongst the twelve areas of legal work most often rated by lawyers as being prestigious. ${ }^{18}$

Many women lawyers have spoken to the Law Commission about how limitations are imposed upon their work experience. A typical comment was made by a lawyer with five years experience who said that she feels pressured to take on women's cases by the fact that

13 Above $\mathrm{n} 5,24$.

14 Above n 6, 22-23.

15 Above n 9, 137-138.

16 Above $\mathrm{n} 9,143$.

17 Above n 9, 137-138.

18 Central/local government legal matters, in which women and men lawyers are almost equally involved, was also rated as one of the twelve most prestigious areas of work. Above n 9, 142. 
she is only invited to meetings in the firm when one of the clients is a woman or where the work is something perceived as "women's law", such as property, wills, matrimonial property agreements or immigration. In her words:

I'm simply not invited to join projects or meet clients where the work is corporate, intellectual property, takeovers or public share listings.

Another woman described how her career in "women's law" became established:

I have recently left a firm I was with for just over 3 years - 9 partners (1 woman). I was the sole staff solicitor and the sole woman in the litigation section. I was hired to attract women clients to the firm (I didn't know that at the time) and I did all the legal aid work so I took on lots of women's cases. To an extent I resented that: I had no great desire to do family work when I started. I wanted to focus on criminal and civil cases and I didn't want to be known as a "women's lawyer". Now that I've moved firms I probably have even more women clients because they are attracted to [this] firm but I feel I have more of a choice now.

Another woman wrote:

I wanted to try litigation in my firm. I was told that as I looked young and was attractive I

"would get ripped to bits in court" because male lawyers wouldn't take me seriously.

\section{B Discrimination}

Gatfield and Gray's study identified discrimination as the second obstacle to women reaching their career goals, with over $75 \%$ of the lawyers surveyed agreeing that discrimination within the legal profession occurs, on numerous grounds. ${ }^{19}$ More women than men held this view: nearly $90 \%$ of the women thought this compared with two thirds of the men. ${ }^{20}$ The lawyers also identified the types of discrimination they had personally experienced during their legal careers: $67 \%$ of the women felt they had been discriminated against in some way, compared with $20 \%$ of the men. The four types of discrimination most commonly experienced by women were: 21

- Sex discrimination, which $65 \%$ of the women and $4 \%$ of the men said they had experienced;

19 The grounds of discrimination identified were sex, age, ethnicity/race, appearance/body shape, sexual orientation, socio-economic status, marital status, disability, political views, religious beliefs and others. The only grounds upon which a higher percentage of men than women had experienced discrimination were ethnicity (experienced by $5 \%$ of men and $4 \%$ of women) and religious beliefs (experienced by $5 \%$ of men and $2 \%$ of women).

20 Above $\mathrm{n} 6,30$.

21 Above n 6, 31. 
- Age discrimination, which $34 \%$ of the women and $11 \%$ of the men said they had experienced;

- Discrimination because of appearance or body shape, which $13 \%$ of the women and $2 \%$ of the men said they had experienced; and

- Discrimination because of marital status, which $13 \%$ of the women and $2 \%$ of the men said they had experienced.

The study found that while partners in firms had experienced less discrimination than other lawyers, women partners had experienced sexual harassment to the same extent as other women lawyers. ${ }^{22}$ Men also reported being sexually harassed, at about one third of the level reported by women. Both men and women lawyers identified partners in firms as the main sexual harassers, and gave this as the main reason why action was not taken when harassment occurred. ${ }^{23}$

Two sets of findings from the Poll of Lawyers are particularly relevant to the issue of discrimination. The responses to questions about career and stress show that the majority of lawyers $(58 \%)$ believe that it is more difficult for women than men to make progress in the profession and that this is a problem for the profession. While $31 \%$ of lawyers overall rate this as a major problem for the profession, $71 \%$ of the women (and $17 \%$ of the men) rate it as a major problem. The $71 \%$ response rate from women lawyers is the highest response made by women to any career and stress issue. The next issue which women identified as a major problem was the high level of stress and burn-out among lawyers which, being identified by $57 \%$ of women and $39 \%$ of men, was the most commonly identified major problem. ${ }^{24}$

Another section in the Poll focused on the three most important problems which the legal profession needs to address in the next five years. The top problem, identified by $30 \%$ of lawyers, is the low public image of lawyers. For women, the second most important problem is "it is more difficult for women than men to make progress in the legal profession". The low priority given to this problem by men, however, resulted in it being ranked 15th equal overall, in a list of 21 issues identified by at least $5 \%$ of lawyers. ${ }^{25}$

22 Sexual harassment was defined to include sexual remarks and innuendoes, unwanted advances and deliberate touching. Above n 6, 33.

23 Above n 6, 33.

24 Above n 9, 104-105.

$2521 \%$ of the women and $3 \%$ of the men identified as a "top three" problem the greater difficulty that women have making progress in the profession. Above n 9, 81 . 
Women lawyers who have made submissions to the Law Commission have provided some graphic contemporary examples of discrimination.

- A lawyer in practice for 6 years in the same firm reported that, at her annual salary review at the end of her third year, the partners told her they were thinking of introducing a bonus scheme whereby for every $\$ 3$ solicitors earned over budget they would retain $\$ 1$. The woman had made $\$ 10,000$ over budget that year and was supportive of the idea. By the next salary review, she had made $\$ 15,000$ over budget and asked about the scheme and was told it was still being worked on. She made it clear that she was keen to be part of such a scheme but did not complain at the slow progress the partners were making on it because she felt happy in the firm and believed that, generally, she was well treated.

The next year, however, when she had earned $\$ 30,000$ over budget and was told again that the bonus scheme was still being worked on, she became sufficiently concerned to mention the matter to one of her male contemporaries at the firm. He was horrified to hear of her situation because, as he told her, he had been on the bonus scheme for the full three years that she had been told it was just an idea.

- Another woman said:

There is still a body of practitioners who hold the opinion that women do not belong in the legal profession. As a barrister I was recently seeking chambers when I visited one set of chambers and was introduced to one of the other members as coming to view the room. The other member's reply was "Is she the new cleaner?" and then he passed a number of sexual remarks. While sexism isn't usually this blatant it nevertheless does exist.

- Another example was provided by a lawyer whose two years work experience at the time had been gained in a small town firm. She wrote this on a standard form questionnaire which we circulated for the primary purpose of obtaining lawyers' views on issues raised by New Zealand women about lawyers' practice. ${ }^{26}$ The last section of the questionnaire asks women lawyers to describe any problems in their dealings with other lawyers which seem to be connected with gender. "Susan Smith" wrote this:

I am given work of lesser value than the male staff solicitor who is junior to me.

I am paid less than the male staff solicitor.

I am given less court work than him. 
I've been told there's nothing worse than a smart woman.

I've been told by one of my male partners "I won't be beaten by a sheila".

The support staff won't assist me as they assist the men and I am given no help addressing this.

I have to do my own typing sometimes, and filing, which no male here would have to do. Then I am told I don't earn enough fees.

I am not allowed to address letters to both husband and wife - only to the husband.

No matter how I dictate them, my memos to older males are always to Mr X from "Susan Smith" - ie, they sign me off using my first name.

My senior partner walked into my office with this [questionnaire] and said "You can answer this crap" - so I have!

Thank you for the opportunity. I know I am good at my job. I know I am unlikely to get where I intend going because I am female.

- This woman's words are also clear:

Good women are forced out of this profession because of male attitudes to family law and female solicitors. I don't know what can be done to help the situation because access to justice is really access to a male paradigm. The Family Court goes some way to addressing this paradigm but it doesn't address the social values behind it. We all do what we can and I try to take a holistic attitude to my work and never judge any woman for her decisions. ... I think my clients get a good deal from me personally. The reality is that I'm thinking of getting out. I'm pissed off with the whole system of family law being viewed as second rate. Always getting difficult clients etc, etc. I don't earn enough to make it worth it. I would be better off being a teacher. That makes me sad because women need women like me and the profession makes it too difficult.

The Poll of Lawyers found that more than one quarter of the women polled were not confident they could work their way up the legal profession if they performed well, compared to $12 \%$ of the men. ${ }^{27}$

\section{Family Commitments}

The third obstacle identified by Gatfield and Gray, to women lawyers reaching their career goals, is family commitments. I doubt that it will surprise many people that women lawyers generally find it more difficult than their male counterparts to balance their paid 
work and family commitments in a way which meets both the profession's expectations about successful work habits and the expectations which exist in society, and therefore in our own homes, about who should be the primary carer for the family.

The 1997 Poll of Lawyers provides some relevant information: ${ }^{28}$

- $53 \%$ of all lawyers ( $56 \%$ of women and $52 \%$ of men) agree with the statement that they are constantly struggling to achieve balance between their career and family life.

- Lawyers with children at home are most likely to agree with that statement: $67 \%$ of lawyers with children at home agree with it, compared with $41 \%$ of those with no children and $46 \%$ of those whose children have left home.

Of course, a lot of lawyers with children at home are men and the Poll does not show the proportions of women and men lawyers with children. But it does reveal that there are four broad groups of lawyers in the profession, identifiable from their responses to questions about their own careers and their views about career advancement.

The groups, and the characteristics which their members are more likely to possess, in light of the demographic profile of the profession as a whole, are as follows: ${ }^{29}$

- Driven Achievers (27\% of the profession)

46-55 years, children have left home, barristers sole or principals, earning over $\$ 100,000$, very satisfied with working life, not getting disillusioned with working in law.

- Achievers with Family Conflict (33\%)

36-55 years, pre-school or school age children, barristers sole or principals, earning over $\$ 100,000$, satisfied with working life, equivocal about whether getting disillusioned with working in law.

- Satisfied Balance (25\%)

under 25 years, no children, employees, satisfied or equivocal about satisfaction with working life, tending to get disillusioned with working in law.

- Low Morale (14\%)

26-45 years, pre-school or no children, employees, earning $\$ 40,000-\$ 60,000$, dissatisfied with working life, getting disillusioned with working in law.

28 Above $\mathrm{n}$ 9, 170 and 171.

29 Above $n$ 9, 173-182. 
What characterises both of the Achiever groups is that these lawyers are more likely to be at the top of the profession or to intend getting there. ${ }^{30}$ The key difference between the two Achiever groups relates to their lifecycle stage: the Driven Achievers, who are more likely to be older and to have children who have left home, are not struggling to balance career and family, unlike the Achievers with Family Conflict. ${ }^{31}$

Lawyers in the other two groups (Satisfied Balance and Low Morale) are more likely to be employees of law firms, have a lower desire to get to the top of the profession and a lower level of confidence that they can in fact get to the top if they perform well. The key difference between these two groups again relates to lifecycle stage: the Low Morale lawyers state most strongly that they are constantly struggling to achieve a balance between work and family whereas the Satisfied Balance lawyers are more likely to be younger and not to have children. ${ }^{32}$

That information, together with the fact that women are more likely than men to have been recently admitted to the profession and that women earn less than men across all categories of legal employment, ${ }^{33}$ supports the conclusion that women lawyers are overrepresented in the two groups which are least satisfied with their working life (Low Morale and Satisfied Balance), and underrepresented in the other two groups which are most satisfied (Driven Achievers and Achievers with Family Conflict). This must raise serious doubts about whether a high proportion of today's women lawyers will stay in the profession.

Relevant to all three obstacles which women lawyers face in achieving their career goals are law firms' Equal Employment Opportunities policies. Both the Poll of Law Firms ${ }^{34}$ and the Poll of Lawyers contain information relevant to EEO. The Poll of Law Firms reveals that half of all New Zealand law firms do not have an EEO policy, that only $6 \%$ of law firms have a formal EEO policy and that the remaining $44 \%$ have an informal policy. Large firms (11 or more partners) are more likely than others to have formal or informal EEO policies. Only $20 \%$ of law firms have a person designated as being responsible for EEO and only $3 \%$ of firms have conducted a review of their EEO policy. ${ }^{35}$

$3019 \%$ of the 485 men polled said they were already at the top of the profession, compared to $6 \%$ of the 173 women. Above n 9, 166.

31 Above n 9, 173.

32 Above $\mathrm{n} 9,174$.

33 Above n 9, 183

34 The New Zealand Law Society - Poll of Law Firms (MRL Research Group, Wellington, 1997). This poll was conducted by a stratified self completion survey amongst 208 law firms. Above n?, .

35 Above n 34, 19. 
In light of that, the responses to the Poll of Lawyers' section on Equal Employment Opportunities, which was focused on lawyers' perceptions of the opportunities provided in their own firms, are particularly interesting. They reveal that a majority of lawyers believe their own firms do provide equal employment opportunities for women ( $71 \%$ believe this), and for people with family commitments (63\%). A significant minority "do not know" if their own firm provides EEO for women (13\%) and people with family commitments $(17 \%)$. Those who believe their firms do not provide equal opportunities for women (15\%) and people with family commitments $(20 \%)$ are more likely to be employees, women, those under 35 years of age and principals from large firms. ${ }^{36}$

By way of conclusion to this brief look at New Zealand women lawyers, I would highlight the gap which seems to exist between the profession's recognition that is more difficult for women lawyers than men lawyers to make progress in the profession (which nearly $60 \%$ of all lawyers agree is a problem and which, for women lawyers is not only the major career and stress issue but the second most important problem facing the profession) and its commitment to doing something about it by way of the adoption of formal EEO policies. To me, the Poll results demonstrate how difficult it is for a minority group - such as women lawyers - to challenge the norms of a system and then, and more importantly, make headway in changing those norms.

\section{GENDER AND THE COURTS}

From the responses made in the Poll of Lawyers to statements about the courts, it is notable that a higher percentage of women than men perceive certain issues to be major problems. The issue which produced the greatest disparity between women's and men's responses relates directly to lawyers' perceptions of gender bias in the courts. Of those polled, $39 \%$ of the women and $5 \%$ of the men agreed with the statement that the judicial system tends to favour men rather than women. ${ }^{37}$

The 1997 Poll of the Public ${ }^{38}$ conducted by the New Zealand Law Society also contains information relevant to perceptions of gender bias in the judicial system. While $57 \%$ of the 500 people ( 245 men and 255 women) polled have confidence that, if accused of a crime, they

36 As has been noted, large firms are more likely to have formal or informal EEO policies and it may be that these partners' responses are informed by their awareness of EEO issues, heightened by their involvement in the process of developing EEO policies. Above n 9, 111-114.

37 The three other issues producing disparate responses are that the costs involved in going to court discourage the public from using the court system $-64 \%$ of women and $53 \%$ of men identified this as a problem; that not all sections of the community have adequate access to the court or ADR procedures - $55 \%$ of women and $38 \%$ of men; and that there is judicial incompetence - $18 \%$ of women and $8 \%$ of men. Above $n 9,98$.

38 New Zealand Law Society Poll of the Public (MRL Research Group, Wellington, 1997). 
would be treated fairly, and $50 \%$ are confident that justice would be done if they were accused of a crime, women are less confident than men on that latter point, with only $42 \%$ of women being confident that justice would be done. ${ }^{39}$

With regard to civil actions, $62 \%$ of the members of the public are confident they would be treated fairly if they were involved in a civil matter and $58 \%$ are confident that a fair result would be achieved. But women who have experience of the civil court or tribunal system $^{40}$ are far less confident about both of those matters than are men who have experience of the civil system. ${ }^{41}$ The researchers commented that this difference between women's and men's perceptions "raises concern over the perceived equality of treatment within the civil system". ${ }^{42} \mathrm{I}$ believe the examples provided in the remainder of this paper help explain women's lower level of confidence in our judicial system.

In 1993, Dr Sheilah Martin QC identified eight common forms of gender bias. ${ }^{43}$

Gender Bias includes:

- the exclusion of women because they are women

- the improper use of stereotypes

- the use of double standards

- the use of a male-defined norm

- the failure to incorporate or be sensitive to the perspectives of women

- not recognising women's harms because they are done to women

- being gender blind to gender specific realities

- using sexist language.

That classification provides an excellent framework for organising the information supplied to the Law Commission about gender equity in the courts.

39 Above n 38, 119-120.

40 Whether as a witness, plaintiff, defendant or in some other capacity. Above n 38, 114.

41 Although the numbers of women and men polled who have experience of the civil system are not large ( 45 women; 64 men) the women were twice as likely as the men to lack confidence that they would be treated fairly and that a fair result would be reached.

42 Above n 38, 121.

43 S Martin "Proving Gender Bias in the Law and the Legal System", in Brockman and Chunn (eds), Investigating Gender Bias: Law, Courts, and the Legal Profession (Thompson Education Publishing Inc, Toronto, 1993), 24-25. 
Before setting out some of the examples gathered by the Law Commission, some general comments are required. First, all of the experiences which follow occurred, to the best of my knowledge, in the past five years. Secondly, while the majority of the experiences occurred in the courtroom, I have included some which focus on lawyers' and other advisors' conduct outside the courtroom, for the very simple reason that what is presented in court is heavily influenced by such conduct outside it. ${ }^{44}$ Finally, it should be noted that a large majority of the women clients who spoke or wrote to the Law Commission had only ever been inside a court in connection with a family matter or, less often, criminal proceedings, so their examples relate to those situations. Indeed, we received a very clear message from the women that, for a great many of them, the prospect of becoming involved in court proceedings over anything other than the crises presented by family breakdowns and criminal charges was a luxury they simply could not afford.

\section{A Exclusion of Women Because they are Women}

- Women lawyers have frequently commented that male Judges and counsel exclude them from full participation in courtroom exchanges and chambers meetings. We have had several reports from women that some Judges do not actually look at women counsel in court and so address all their comments and questions either to thin air or to male counsel.

- It is not only junior women counsel who have made these sorts of comments.

The words of two women lawyers help explain the situation:

I have experienced a disdain from some older members of the judiciary yet seen those same Judges be matey with other, male, counsel. I've got the feeling I've been frozen out although this is never directly said - it's very difficult to put your finger on or draw attention to. Sometimes this unwelcoming attitude has made me question my ability when in fact there has usually been no need to do so.

Undue deference is paid to senior male practitioners by some Judges. If the plaintiff or applicant has female counsel acting, the Judges seem to overlook them and ask the opposition what the case is about.

\section{B Improper Use of Stereotypes}

- One lawyer wrote about a case in which she was acting for a woman whose marriage had broken down and who was caring for the children. In court, male opposing counsel said of the woman, in a manner which suggested she was taking the

44 Many further examples of gender bias beyond the courtroom, influencing the conduct of legal proceedings involving women, are provided in the consultation papers published in the Women's Access to Justice project. 
easy option, that she had given up work and was now on a benefit. The lawyer wrote:

Lawyers (and it can be both sexes) don't appreciate the commitment and hard work involved in caring for children, in particular after separation. ${ }^{45}$

- We have heard from several women lawyers that when they appear as senior counsel with a male junior, male opposing counsel often assume that the women are the juniors.

- A Maori woman lawyer in practice for seven years reported that court staff quite often assume she is the defendant and that on one occasion she was barred by staff from making her way to her place in court and told to go and sit outside.

- A young woman charged with a traffic offence wrote that one of the JPs hearing the case told her that he did not believe her testimony because "young ladies shouldn't have tattoos and ride motorbikes".

- A lawyer reported that a Judge sentencing a woman for theft referred to the defendant several times as an attractive young woman, adding on one occasion that she was "an attractive young woman who does not need to resort to this sort of behaviour". Also, when the size of the clothing she had stolen was mentioned, the Judge expressed surprise that it was size 12 because, he said, he would have thought the defendant was a size 10 .

- One example which several lawyers have mentioned concerns a lawyer who was heavily pregnant when she was assigned a client on criminal legal aid. She asked the Judge for a remand without plea for three weeks and, when asked why she wanted that amount of time, explained that her baby was due very soon and that three weeks would allow her to have the baby and continue acting for the client. Apparently the Judge looked around the court before saying, in a manner which seemed calculated to draw attention to his words, "Two weeks remand without plea - and if you're unavailable then the assignment can go to someone else".

The lawyers who have referred to this example believe that the stereotypes which played a part in the Judge's ruling are those about who is the breadwinner in a family and how long a woman needs or, perhaps, should take, after having a baby before returning to paid work. In this case, however, as the lawyers who have given the example know, the

45 I would add my own observation that many people may be unaware that the costs of childcare are prohibitively expensive for many women to afford out of the earnings they can command. For example, to have two pre-schoolers cared for during office hours in a city creche costs $\$ 350$ a week $(\$ 18,000$ per annum). 
pregnant lawyer is the breadwinner in her family and had returned to work immediately after the birth of her other children.

Women litigants, and lawyers, have frequently reported the difficulties they encounter, when preparing for matrimonial property proceedings, in getting accountants, valuers and banks to act fairly towards the women.

- One example, provided by a lawyer, concerned a woman who lived in a small farming community and who jointly owned a farm with her husband. When the couple separated, their bank manager made joint dairy cheques available only to the husband, until he was threatened with legal action, and the couple's accountant refused to make the farm accounts available to the wife's solicitor.

- A lawyer reported that at an adoption meeting the Judge said that the little boy would grow up to be a rugby player and the little girl a ballerina.

- A young mother who opposed her own mother's application for custody of the baby reported that the Judge said to her at the mediation conference "And why should a pretty little girl like you want to argue with your mother all the time instead of getting out and having a good time?"

\section{Use of Double Standards}

- Women lawyers often make comments to the effect that if they adopt the same adversarial stance as their male opponents, some opposing counsel and Judges regard them as being unreasonable or aggressive but that if they do not adopt that stance the same people do not take them seriously.

- We have been told that in custody matters it can still happen that counsel for the father will raise, as a negative characteristic, the fact that the woman is a "working mother".

- A lawyer reported that a Judge told a woman defendant who was being sentenced, "You're a mother - you should know better".

- Another lawyer wrote that she believed the Court had made much more of the fact that a woman client had convictions for violence than would have been the case if her client had been a man.

\section{Use of a Male-Defined Norm}

- A woman in a family matter who was advised by her lawyer not to have an "emotional outburst" in front of the Judge as that could cost her the case, wrote: 
appear to be able to hear what is said by a woman client unless she manages to be cool and "rational". They seem to "switch off" and ignore what she is saying because of the way she is saying it.

- A lawyer reported that in a difficult case where a woman was applying for protection orders, the Judge criticised the woman's way of talking, saying that it gave him a headache.

- Many women lawyers have mentioned the discomfort of court dress during pregnancy and some have said that it is difficult to stand for long periods of time in court when pregnant.

- One woman lawyer commented that witnesses should be able to sit down when giving evidence because she feels faint standing for any length of time when she is menstruating and knows that other women do too.

- Another woman, upon hearing me use the previous example, exclaimed with relief that I had mentioned it and added that women counsel often talk amongst themselves of the discomfort they experience when menstruating and trials go on for hours without any breaks.

- A woman defendant said:

I was on trial and I had a really bad period pain and I was sitting in those desks you know, and just kind of wriggling around and feeling really uncomfortable and feeling really ill and the Judge said to me "I am concerned you are not taking these proceedings seriously enough. If you do not sit still I will put you in contempt of court.

Some of the most frequently mentioned examples concern the facilities, or lack of them, at some courthouses: the lack of places for children to play and for babies to be fed and changed.

- One woman, speaking of the number of women appearing in bankruptcy matters - the so called sexually transmitted debt cases - said that it is very distressing

. . . when women turn up with young children, the victim of executing a husband's guarantee, even for a credit card, the husband's often left the country and the women are unable to get legal advice.

They are always embarrassed in courtrooms with no counsel, often with young children, even babies, and no facility nearby which is clearly available to them to leave the children, unlike the hospital creches.

- Another woman wrote of a particular courthouse: 
There are no facilities for children. We tried to set up a creche here but they wouldn't listen to us. There is not even a changing room available for young mothers and their babies. One mother I know arrived at the court at 9.00am and she was still sitting there at $5.00 \mathrm{pm}$ that afternoon. The court people had forgotten about her. She had her child with her all day and was too scared to leave just in case she had a warrant served on her.

Another commonly voiced criticism is of the length of time which people must spend at court waiting for their case to be called, especially if they must travel long distances to and from court or have children for whom it is difficult to arrange or afford care.

- One woman wrote:

I actually went to court one day and I was meant to be the first case heard and they'd decided to give us the whole day, but because it was a Monday morning a whole lot of other things were put in front of us. I didn't get into court until $4.30 \mathrm{pm}$. In the meantime my two kids were being babysat and I had to keep ringing up and saying, you know, the court hasn't heard my case. I'd gone in for 10 minutes and he says "Oh, we'll probably adjourn this".

\section{E Failure to be Sensitive to the Perspectives of Women}

- One example arose in a case where a Judge was about to sentence a woman. The presentence report had been agreed but there was one matter upon which defence counsel wanted to update the Judge: her client was pregnant. When the Judge heard that, he is reported to have smiled and said he had thought that was so. Counsel, who knew her client had just found out, asked why the Judge had thought that. The Judge replied in words to the effect that, having spent a lot of time on the farm, he could tell when a cow's been taken by the bull because she has a certain lilt to her gait.

- We have received many comments that, because Victim Impact Reports have written on them that they will be shown to defence lawyers, the probation officer and the defendant, most women are very loath to say what they would like to for fear of enraging the defendant, when they have no guarantee that he will be sent to gaol, let alone for a lengthy period.

- All too frequently mentioned are the lack of places in or near courthouses for women complainants to wait separately from those who have abused them and the friends and families of the abusers; and the lack of separate entrances to courtrooms so that victims can enter and leave without walking past those same people.

- One woman lawyer admitted to being fearful in court when a woman is applying for a protection order, the respondent is present and

I'm the only thing between them and there's no security. 
- An example from the juryroom was provided by a woman who has served as the foreman (a sexist term, she noted) of two juries. She reported that in both cases, when it was time for the jury to deliberate, there were men who had made up their minds and were intent on bullying the, mainly older, women members into agreeing so that they could all go home. In her letter to the Law Commission, she recommended that Judges' directions to juries include a statement about taking time to contemplate, to look at exhibits, to work out in one's own mind what has happened and to discuss it with the other jurors. While she said that in both cases she was able to give the other jurors time to think and have their say, she added that it took real leadership skills on her part to create the environment in which that was possible.

\section{F Not Recognising Women's Harms Because they are Done to Women \\ and}

\section{Being Gender Blind to Gender Specific Realities}

Under both of these heads, I could give a large number of examples relating to violence against women. The first example is lengthy; as is the period of time during which women typically suffer family violence before coming to the attention of the justice system.

- A woman spoke to us by telephone about her most recent experience in court, after her ex-husband breached a non-molestation order for the fifth time in three years. She had just found out that he had been imprisoned, on two charges, for two months. The last time he breached the order, he was imprisoned for the maximum of three months. She could not understand why he had not received that sentence again. In her view, the latest breaches were more serious: he was physically violent in the past but lately has been stalking her - parking his car down the road and watching her house, driving past several times a day, and throwing things at the doors and windows in the middle of the night. She is convinced that he broke into her house some time ago and stole many of her personal possessions, including her underwear. He was convicted of receiving in relation to that incident but there was no proof that he committed the burglary. He has been denied access to their two primary school age sons for eighteen months because of his past behaviour, which included making threats, in front of them, to kill her. The boys developed behavioural problems when their father had access and started wetting their beds again. She said that she lives in a state of constant fear and expects that sooner or later her ex-husband will "go nutty again" and kill her.

At the time she spoke to us, she had not told her two sons that their father knew where they lived. Keeping that knowledge from them, she said, had compounded her constant fear that he would arrive at any time. She said that all her behaviour has changed and she believes that Judges do not understand this. She pulls her blinds down before it gets dark, 
always keeps the gates locked and gets friends to check her house if she goes away. Her biggest fear is arriving home and finding her ex-husband there but she cannot afford an alarm system for the house: the cheapest one costs $\$ 1000$ and if she borrowed that amount she has no way of repaying it.

She said that at the latest court hearing, her ex-husband had a new lawyer who was very abusive towards her. The Judge intervened on her behalf on several occasions but that did not stop the lawyer yelling at her and making false accusations, including that she had recently spent a night with her ex-husband. Because she is terrified of her ex-husband, she gave her evidence and left the court and was appalled to hear later, from the Police, that the maximum sentence had not been imposed. The Police told her that the Judge, in his summing up, had said some harsh words about her ex-husband and that he was going to disregard his evidence. The Judge had also said that he had found the woman and her witnesses to be very credible. She said that she feels that she has had enough and that next time her exhusband breaches the order she will not report it, although the Police have told her to keep reporting breaches and, in her words, have been "brilliant" throughout.

Many women who have been in violent relationships and mustered the courage and resources to leave, have said that their lawyers have made ill-informed comments about the man's demeanour, (such as "He wouldn't do that - he's not that sort of person") based on their own knowledge of or, more usually, assumptions about him. These examples could, therefore, also be classified as the improper use of stereotypes.

- One woman described how frustrating it was that her lawyer did not believe how determined and violent her husband could be.

He said things like "he's a bit bitter now but he will calm down in a couple of months". At this stage he was ringing my mother to say he was going to get me and was telling me he'd see me dead in the gutter.

- A community service agency wrote about a woman with four children who had left a violent relationship and was helped to set up in a house with an address unknown to the husband. The husband had access to the children on terms which kept him away from the woman but breached those terms by taking the children out of town and failing to return them. The woman's lawyer advised her to "go and be nice to him and get the children back". The woman then felt she had no choice but to accept her lawyer's advice, and the court's subsequent order, that her husband be given her address and that she act as the supervisor of his access visits. The man immediately came to the house and refused to leave. The woman and the four children left and slept in cars before finding alternative accommodation.

- A woman lawyer wrote about a client who had suffered ten previous breaches of non-molestation orders. In the last violent incident, there was blood on the walls. 
The police, who were very supportive of the woman, were sure that "this time" the man would be sent to prison. He was not, however. The lawyer wrote:

... the husband's excuse for visiting the wife's house was that he wanted to see their child even though some of the earlier offences occurred when he was exercising access to the child at his place: he used to leave the child there and go and beat up the mother.

That same case has another aspect to it which we have heard about very often: that women victims of violence are just too scared of and worn down by their partners to fight for their rights in other areas. In that same case, there was a custody dispute and, in the words of the woman's lawyer:

in the end, the woman offered the husband the house (ie, she would not claim half) in return for her having custody of the child. This was offered in court - the Judge was aware - and the husband agreed. This meant he had the house, and the mother and child were homeless. The husband also said he would no longer require access to the child: he didn't really want custody or access at all.

- Another example concerns a woman with two pre-schoolers who literally ran away from her violent husband and the farm they lived on - with the children, a car for which she had secretly had a spare key made, two plastic bags of clothes, and $\$ 60$. She went to Women's Refuge. These are her words:

The Judge tried to "order" that I alone take the children to my husband's place for their access despite the round trip being approximately $160 \mathrm{kms}$ and my husband having a nonmolestation order against him and the fact that it took me six years to get out of a violent and destructive marriage.

I found the Judge's speech to be very upsetting, like putting your head in a lion's mouth. My husband had made numerous threats against the children and myself which the Judge was well aware of.

- Another woman wrote:

I [had] to get out of the family house because my ex-husband regarded it as his castle ... And I found this little hovel which we ended up in and then I couldn't get anything for the children ... I didn't have a washing machine, no fridge, no blankets, no anything. I couldn't even get their school clothing for the older two. We had two cars - I couldn't get one of the cars ... the Judge sat up in court [and] said Mrs so-and-so, she can go to one of her parents to do her washing - and both my parents are dead. You know making these wild statements about how I could get help but nothing practical to help me and the children. 


\section{G Using Sexist Language}

This form of gender bias covers much more than what I have heard Dr Sheilah Martin QC describe as pronoun envy. However, the use of inclusive or gender neutral pronouns is an essential first step in avoiding gender bias.

- Many women lawyers have commented on the fact that they have to announce themselves in court as either Ms, Miss or Mrs, when male counsel just say their surnames, and that if they introduce themselves as Ms, some Judges and opposing counsel seem to deliberately call them Miss throughout the proceedings.

- Another fairly common example we have heard is of Judges greeting counsel as "Gentlemen" when women counsel are present.

- A woman at a Family Court mediation reported that the Judge called her "Mum" throughout when, as she said, "I am most certainly not his mother" and added

To me this was belittling, especially when they command respect for their own position, ie we call them Sir, Your Honour.

- Some women lawyers count body language as sexist language, referring to Judges who roll their eyes when they or women witnesses are speaking, or who stare at women counsels' legs.

\section{CONCLUSION}

At the AIJA Equality and Justice conference in October 1995, ${ }^{46}$ one of the presenters listed six prerequisites for avoiding gender bias. They are these:

1 Be aware of the law's historical approach to women.

2 Be aware of the facts about women's position in society.

3 Have an understanding of the meaning of equality.

4 Be aware of gender myths and stereotypes.

5 Be prepared to question your own perspectives and values.

6 Have an empathetic understanding of people from a different background and having different experiences from your own. ${ }^{47}$

Obviously, the Judicial Seminar on Gender Equity provides a unique opportunity for New Zealand Judges to explore the meaning of each of those vitally important matters.

46 Held at Ballarat for Judges and Magistrates of the State of Victoria.

47 Professor M Neave, oral commentary on session of conference. 
This contribution to the discussion has focused on women's experiences in the legal profession, and in court, in order to highlight how gender counts, as it does in society generally, to women's detriment. What has not been explored here are the socially constructed factors other than gender - particularly of minority ethnicity, disability, and sexuality - which cause wide disparities in the experiences of different groups of women and which also, free of gender's stigma, disadvantage large numbers of New Zealand men in their dealings with this country's social systems. The comments made to the Law Commission during its consultations in the Women's Access to Justice project, especially by Maori women, suggest that the above list of prerequisites for avoiding gender bias could, with appropriate amendments, form the basis of future seminars which explore the effects of those other socially constructed factors upon New Zealanders' perceptions of and participation in our justice system. 